\title{
Evidence Associated with the Use of Oxazolidinones for the Treatment of Skin and Skin Structure Infections: A Retrospective Study
}

\author{
Evidência Associada ao Uso de Oxazolidinonas no \\ Tratamento de Infeções da Pele e das Estruturas \\ da Pele: Estudo Retrospectivo
}

\author{
João GONÇALVES-PEREIRA $\triangle^{1,2}$, Filipe FROES ${ }^{3}$, Fernanda Paula SANTOS ${ }^{3}$, Helena Sofia ANTÃO ${ }^{4}$, \\ João Paulo GUIMARÃES ${ }^{4}$ \\ Acta Med Port 2019 Jun;32(6):453-458 - https://doi.org/10.20344/amp.11494
}

\begin{abstract}
Introduction: Skin and skin structure infections are an increasing cause of hospitalization. Although mortality is relatively low, skin and skin structure infections are associated with prolonged hospital length of stay and high costs. Oxazolidinones have been suggested as a tool to treat infected patients in the ambulatory setting in order to decrease hospital length of stay. We wanted to address the evidence associated with the use of oxazolidinones in the treatment of skin and skin structure infections.

Material and Methods: In this observational retrospective study we analyzed the anonymized diagnosis related group coded information from the Portuguese database for hospital admissions, that included all adult patients with a diagnosis of oxazolidinone use and a SSSI, discharged between 2010 and 2015.

Results: During the study period, a total of 5518 patients had a diagnosis of oxazolidinone treatment. We selected 483 of those who were also diagnosed with a skin and skin structure infections. Their mean age was 64.9 years and $62.7 \%$ were male. The median hospital length of stay was 27 days (Inter quartile range $13-56$ ) and the mortality rate was $12.6 \%$. The prevalence of secondary anemia and of thrombocytopenia in the whole group treated with oxazolidinones was $2.5 \%$ and $3 \%$, respectively.

Discussion: Despite the high bioavailability of oxazolidinones, we were not able to find evidence that its use was associated with a decrease of mortality or hospital length of stay (due to early discharge) of patients with skin and skin structure infections.

Conclusion: In this study we were not able to find evidence that oxazolidinones had any clinically significant benefit. A structured approach, including antibiotics with favorable pharmacokinetic and safety profile as well as a carefully planned ambulatory follow up may be needed.
\end{abstract}

Keywords: Hospitalization; Oxazolidinones; Skin Diseases, Bacterial/drug therapy; Soft Tissue Infections/drug therapy

\section{RESUMO}

Introdução: As infeções da pele e das estruturas da pele são uma causa crescente de hospitalização. Apesar da baixa mortalidade, as infeções da pele e das estruturas da pele estão associadas a internamentos prolongados e a custos elevados. O uso de oxazolidinonas foi proposto como estratégia para o tratamento ambulatório destes doentes como forma de reduzir a duração do internamento. Pretendeu-se avaliar a evidência associada ao uso de oxazolidinonas no tratamento de infeções da pele e das estruturas da pele. Material e Métodos: Neste estudo retrospectivo observacional analisámos a base de dados portuguesa anonimizada, codificada por grupos de diagnóstico homogéneos. Incluímos adultos com alta hospitalar entre 2010 a 2015 com diagnóstico de alta de utilização de oxazolidinonas. Nesse grupo selecionamos os que apresentavam diagnóstico concomitante de infeções da pele e das estruturas da pele.

Resultados: Durante o período em estudo 5518 doentes receberam o diagnóstico de tratamento com oxazolidinona. Destes selecionámos 483 com diagnóstico concomitante de infeções da pele e das estruturas da pele. Destes, $62,7 \%$ eram homens e a idade média foi de 64,9 anos. A duração mediana do internamento hospitalar foi de 27 dias (intervalo interquartil $13-56$ ) e a taxa de mortalidade foi $12,6 \%$. A prevalência de anemia secundária, nos 5518 doentes tratados com oxazolidinonas, foi de $2,5 \%$ e a de trombocitopénia foi de $3 \%$.

Discussão: Apesar da elevada biodisponibilidade das oxazolidinonas, neste estudo não conseguimos identificar evidência que o seu uso estivesse associado a diminuição da mortalidade ou da demora média hospitalar (relacionado com alta precoce) dos doentes com infeções da pele e das estruturas da pele.

Conclusão: Neste estudo não encontramos evidência de que a utilização de oxazolidinonas esteja associada a benefícios clínicos significativos. Estratégias integradas, incluindo antibióticos com bom perfil de segurança e de farmacocinética, bem como planeamento adequado para seguimento em ambulatório parecem ser necessários.

Palavras-chave: Doenças Bacterianas da Pele/tratamento; Hospitalização; Infecções dos Tecidos Moles/tratamento; Oxazolidinonas

\section{INTRODUCTION}

Skin and skin structure infections (SSSI) are among the most frequent human bacterial infections. Skin and skin structures infections typically involve deep soft tissue and represent an increasingly significant cause of hospitalization. ${ }^{1-3}$ Moreover, these infections often occur in patients

1. Intensive Care Department. Hospital de Vila Franca de Xira. Vila Franca de Xira. Portugal.

2. Nova Medical School. Lisbon. Portugal.

3. Intensive Care Unit. Chest Department. Hospital Pulido Valente. Centro Hospitalar de Lisboa Norte. Lisboa. Portugal.

4. Medical Department. Angelini. Lisbon. Portugal.

$\square$ Autor correspondente: João Gonçalves Pereira. joaogpster@gmail.com

Recebido: 30 de outubro de 2018 - Aceite: 08 de março de 2019 | Copyright @ Ordem dos Médicos 2019 
with significant comorbidities and frailty and are associated with substantial health costs, ${ }^{4,5}$ prolonged hospital length of stay (LOS) and frequently require complex nursing care or even a surgical intervention. ${ }^{4-6}$ Diabetes seems to be an important risk factor and may increase the incidence as much as $50 \%$. $^{3}$

Compliance with international guidelines is poor and patients are often managed according to local practices. ${ }^{7}$ This reinforces the need for hard patient centered evidence in this field.

Even in patients admitted to Intensive Care Units, SSSI may represent a substantial burden, representing as much as $5 \%-6 \%^{8,9}$ of the total number of infections, and seem to be more common during Spring and Summer. ${ }^{9}$

Most SSSI are caused by Gram positive bacteria, especially Staphylococcus aureus and $\beta$-haemolytic Streptococci. 3,10 The prevalence of Staphylococcus aureus seems to be increasing and has become the single most reported pathogen. ${ }^{1,11}$

Usually, SSSI are treated with antibiotics and surgical drainage, as appropriate. However, the emergence of strains resistant to multiple agents has complicated antibiotic choices. ${ }^{4,10}$ Overall, the most problematic SSSI are caused by methicillin-resistant Staphylococcus aureus (MRSA). ${ }^{1}$ Both community-acquired (CA) and hospital-acquired (HA) MRSA have become predominant pathogens in nosocomial SSSI, making these infections increasingly challenging to treat. ${ }^{11,12}$

The requirement of hospitalization for these patients is mostly related to the need of surgical debridement, nursing care and intravenous antibiotics. Outpatient parenteral antibiotic treatment (OPAT) has been suggested as an appropriate and safe alternative, with lower costs and improved patient satisfaction. ${ }^{13}$ More recently, the development of oral antibiotic drugs with high bioavailability, that are effective against MRSA, has created another cheaper alternative to OPAT. ${ }^{14,15}$

Moreover, antibiotics with high oral bioavailability may be given to patients already admitted to the hospital, in order to facilitate an earlier discharge. Oxazolidinones rank high on this approach to treat SSSI, although some studies failed to show a benefit of these drugs in the reduction of hospital LOS. ${ }^{16}$ The need for complex nursing care, fear of drug toxicity, especially hematological toxicity and doubts about antibiotic compliance in the ambulatory setting may preclude this strategy.

The aim of this study was to evaluate if the use of oxazolidinones was associated with improved clinical outcomes in patients with SSSI, namely lower mortality and lower hospital LOS, when compared with previously published data.

\section{MATERIAL AND METHODS}

The Central Administration of the Health System of the Portuguese Ministry of Health contains administrative and clinical data of all admissions to hospitals from the national health service which covers the whole population of mainland Portugal. This information, including diagnoses and procedures, is diagnosis related group (DRG) encoded.
DRG coding is performed by trained physicians and based on hospital discharge reports, according to the International Classification of Diseases, $9^{\text {th }}$ Revision Clinical Modification (ICD-9-CM). DRG codings are periodically audited.

In this study, we retrospectively analyzed all hospital admissions of adults with a report of oxazolidinone use (ICD-9-CM 00.14), who were discharged between 2010 and 2015. Patients under 18 years of age were excluded.

We focused our analysis on the use of oxazolidinone to treat a SSSI. We screened the first 10 diagnoses of all the included patients and segregated patients with a diagnosis of a SSSI, namely erysipela (ICD-9-CM 035), cellulitis or abscess of hand or fingers (681.xx), other cellulitis or abscesses (682.xx), other local SSSI (686.xx), impetigus (684), folliculitis (704.09), diabetic foot infection (249.80, $250.81,250.80)$, sore pressure ulcer (707), other post traumatic wound infection (958.3), post surgical infection (998.5x e 998.83), human or animal byte (E906.5) or gangrene (785.4).

To focus our study only on the use of an oxazolidinone to treat SSSI, we excluded from further analysis patients who also had a diagnosis of another infection at any other focus site, especially endocarditis, osteomyelitis, pneumonia, burns and necrotizing fasciitis.

Finally, we checked the selected records for the presence of comorbidities, especially diabetes (ICD-9-CM 250). In order to address the incidence of toxicity, especially hematological toxicity, we evaluated all the population with a diagnosis comprising oxazolidinone use for the presence of secondary thrombocytopenia (ICD-9-CM 287.4 and 287.5) or anemia (ICD-9-CM 284.xx). We also calculated the mortality rate of patients presenting any of these diagnoses.

The study was submitted to the Central Administration of the Health System of the Portuguese Ministry of Health who approved the protocol and provided the requested data.

The analysis of clinical information preserved total patient anonymity and only anonymized data was analyzed. No database with patients' identification was created. Therefore informed consent was waived. Descriptive statistics were performed, namely absolute $(n)$ and relative frequencies (\%) for qualitative variables and mean \pm standard deviation (SD) for quantitative variables. Statistical analyses were carried out using STATA $®$, Version 15 , statistical software system.

This study was performed in accordance with the Helsinki Declaration for Human Research.

\section{RESULTS}

A total of 5518 patients were discharged from the hospital with a diagnosis of oxazolidinone use during the study period. We checked the first 10 discharge diagnoses from all patients and segregated those with a diagnosis of a SSSI. We excluded patients with an infection at any other site, regardless of concomitant SSSI. Overall, 483 patients with a discharge diagnosis of one or more SSSI were selected.

Mean age was 64.9 [standard deviation (SD) 15.1], including $56.1 \%$ older than 65 years and $29 \%$ older than 
Table 1 - Skin and soft tissue infections of patients treated with oxazolidinones

\begin{tabular}{lc}
\hline $\begin{array}{l}\text { Erysipela (ICD-9-CM 035) } \\
\text { Cellulitis or abscess of hand or fingers } \\
\text { (ICD-9-CM 681.XX) }\end{array}$ & $48(3.7 \%)$ \\
$\begin{array}{l}\text { Other cellulitis or abscesses (ICD-9-CM 682.xx) } \\
\text { Other local acute bacterial skin and skin } \\
\text { structures infection (ICD-9-CM 686.xx) }\end{array}$ & $348(26.7 \%)$ \\
Impetigus (ICD-9-CM 684) & $23(1.8 \%)$ \\
$\begin{array}{l}\text { Folliculitis (ICD-9-CM 704.09) } \\
\text { Diabetic foot infection } \\
\text { (ICD-9-CM 249.80, 250.81, 250.80) }\end{array}$ & 0 \\
$\begin{array}{l}\text { Sore pressure ulcer (ICD-9-CM 707) } \\
\text { Other post traumatic wound infection } \\
\text { (ICD-9-CM 958.3) }\end{array}$ & 0 \\
$\begin{array}{l}\text { Post-surgical infection } \\
\text { (ICD-9-CM 998.5x + 998.83) }\end{array}$ & $10.1 \%)$ \\
Human or animal byte (ICD-9-CM E906.5) & $479(29.1 \%)$ \\
Gangrene (ICD-9-CM 785.4) & $388(29.8 \%)$ \\
\hline
\end{tabular}

Discharge diagnosis $(n=1303)$ of patients who received oxazolidinones during hospital stay with a skin or skin structure infection. A single patient could have more than one skin and skin structures infection. Patients with other infection focus were excluded from analysis and are not represented in the table.

75 years. Only 30 patients were younger than 40 years. Male sex was predominant (62.7\% of this patients group).

Cellulitis and abscess (77\%), pressure sore ulcer infection $(78.5 \%)$ and post-surgical infections (80.3\%) were all very commonly diagnosed (Table 1). Even though diabetes was a common comorbidity, being diagnosed in $27.7 \%$ of patients, only 1 patient presented a diabetic foot infection.

Comorbidities were common, especially diabetes (Table 2). Its prevalence increased with age, being present in more than $70 \%$ of patients aged over 60 years (Fig. 1). Older age was common but $10 \%$ of patients were younger than 50 years.

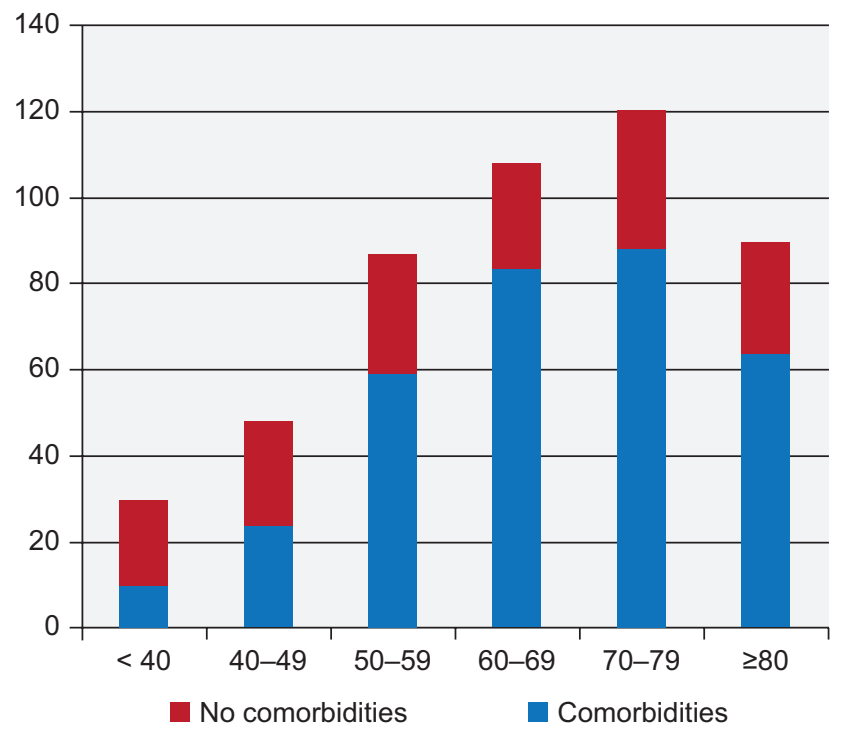

Figure 1 - Distribution of patients according to age and the presence of comorbidities
Table 2 - Concomitant comorbidities of patients with skin and soft tissue infections

\begin{tabular}{lc}
\hline $\begin{array}{l}\text { Cerebrovascular disease } \\
\text { (ICD-9-CM 430.XX - 438.XX) }\end{array}$ & $9(1.9 \%)$ \\
$\begin{array}{l}\text { Dementia (ICD-9-CM 290.XX) } \\
\text { Chronic cardiac failure (ICD-9-CM 428.XX) }\end{array}$ & $9(1.9 \%)$ \\
$\begin{array}{l}\text { COPD and respiratory failure } \\
\text { (ICD-9-CM 491.XX+ 492.XX+518.8X) }\end{array}$ & $19.5 \%)$ \\
$\begin{array}{l}\text { Chronic renal failure } \\
\text { (ICD-9-CM 585.XX-586.XX) }\end{array}$ & $86(17.8 \%)$ \\
$\begin{array}{l}\text { Chronic hepatic failure } \\
\text { (ICD-9-CM 571.XX+572.8) }\end{array}$ & $9(1.9 \%)$ \\
$\begin{array}{l}\text { Atherosclerosis (ICD-9-CM 440.XX) } \\
\text { Diabetes mellitus (ICD-9-CM 250.XX) }\end{array}$ & $50(10.4 \%)$ \\
Neoplasic disease (ICD-9-CM 140.XX-208.XX) & $248(51.3 \%)$ \\
\hline
\end{tabular}

Number of patients treated with oxazolidinones for a skin and skin structure infection who also presented a discharge diagnosis of significant comorbidities. Only 156 patients $(32.3 \%)$ did not have at least one of these diseases.

Hospital LOS was very long, with a median of 27 days [Inter quartile range (IQR) 13 - 56] and an even higher mean value of 45.4 days (SD 56.9), related with some patients having a very prolonged hospital stay. These figures remained similar even after excluding patients who died (median 24 days [IQR 13 - 46]; mean 43.1 days (SD 55.2)). Mortality rate was also very high (12.6\%), even though only 7 patients were admitted to an Intensive Care Unit (Table 3).

In the whole population (5518 patients with a diagnosis of oxazolidinone use), the prevalence of secondary anemia was $2.5 \%$; thrombocytopenia was diagnosed in $3 \%$ of this population. These two groups had both a significantly higher mortality rate (chi-square test: $33.6 \%$ vs $45.7 \%, p=0.003$; and $33.6 \%$ vs $43.4 \%, p=0.009$, respectively).

\section{DISCUSSION}

In this study we address the clinical use of oxazolidinones to treat SSSI in patients admitted to the hospital. We found that this group had a high mortality rate, $12.6 \%$, and also a very long hospital LOS (median 27 [IQR 13 - 56] days). Consequently, we were not able to find any evident benefit regarding the use of these drugs in this hospital population.

We believe that the high mortality and prolonged hospital LOS are mostly related with comorbidities and not necessarily with the infection itself. Figtree et $a /^{17}$ found that the presence of bacteremia or low albumin levels (that can be seen as a marker of frailty and chronic inflammation) were independent predictors of mortality in SSSI.

Table 3 - Clinical outcomes

\begin{tabular}{ll}
\hline Clinical outcomes & Study population $(\mathrm{n}=483)$ \\
Mortality, $\mathrm{n}(\%)$ & $61(12.6 \%)$ \\
$\begin{array}{l}\text { Length of hospital stay, days, } \\
\text { median [Interquartile range] }\end{array}$ & $27[13-56]$ \\
Admission to ICU, $\mathrm{n}(\%)$ & $7(1.4 \%)$ \\
\hline
\end{tabular}

ICU: intensive care unit 
Furthermore, age over 60 years, infection with MRSA, symptoms duration of more than four days before hospital admission, were also associated with a hospital LOS longer than seven days. This old age and high prevalence of comorbidities, that we identified in our population (Fig. 1), were also found in other studies. ${ }^{9,18}$ In fact, the increasing number of patients with multiple comorbidities (especially diabetes) that are admitted with an infection represent a significant burden for the health system, not only due to the required prolonged hospitalization, but also because it may be challenging to treat these patients appropriately. This population has a frequent exposure to health care facilities and antibiotics, which can lead to an increase in the number of resistant microorganisms and, therefore, to a higher risk of therapeutic failure, infection recurrence and death. ${ }^{9}$ In an international, multicenter, observational, retrospective study, including 1995 patients with a SSSI, ${ }^{19}$ comorbidities were present in $78 \%$ (diabetes in $34 \%$ ) and infection recurrence was noted in $26 \%$. Nevertheless, the mortality rate was only $3.4 \%$ and hospital LOS 18.5 [12], ${ }^{19}$ figures were lower compared to our population.

Usually, selection of the antibiotic treatment for SSSI is based on the clinical presentation, host comorbidities, medical history and infection focus. ${ }^{10,20}$ However, the rise of resistant pathogens (especially MRSA), even in patients without known risk factors, ${ }^{21}$ has increased the importance of diagnostic microbiology and antibiotic susceptibility testing. Such actions can promote appropriate antibiotic prescribing and stewardship. ${ }^{22}$

Some studies have reported high rates of MRSA in SSSI or similar infections, both CA-MRSA and HA-MRSA, ranging from $22.4 \%$ to $74.8 \%$, ${ }^{1,12}$ but with important geographic variations. ${ }^{23}$ In Portugal CA-MRSA has already been reported, ${ }^{24}$ but HA-MRSA clearly predominates.

Our Portuguese group of patients presented a very high mortality rate, $12.6 \%$, which is much higher than in other published studies (ranging from $0.4 \%$ to $5.2 \%$ ). ${ }^{18}$ We believe that this difference may be due to selection bias, as a consequence of the criteria that were used. Only patients that received a diagnosis of an oxazolidinone use were included in this group. These antibiotics were commonly used as a rescue therapy, in patients with severe disease, who had already failed other lines of therapy, especially vancomycin. Taking into account the specificities of the Portuguese DRG Hospital Funding Model, physicians are more likely to code 'oxazolidinone use' when this antibiotic is used as an exception, namely in rescue therapy. In fact, no patient with less severe disease, either impetigus or folliculitis was included in this series (Table 1).

These patients, who fail their first line of therapy, usually have more comorbidities, more severe infections including organ failure, often have frailty associated with immunosenescence,${ }^{26}$ and have an increased risk of dying.

Positive impact from the use of oxazolidinones, as first therapy to treat SSSI, is noted in some metanalysis, ${ }^{27}$ including the 2016 revised Cochrane review. ${ }^{28}$ Furthermore, this benefit seems to be mostly related to 'clinical cure' but with no clear impact in mortality. Furthermore, conflicting clinical results are commonly reported, and studies reporting benefits are often industry funded. ${ }^{28}$

One of the main interests in the use of oxazolidinones for SSSI is the possibility of their use as outpatient oral therapy. These drugs have an excellent oral bioavailability and maintain their large spectrum of activity, even when given by oral route in the ambulatory setting. ${ }^{30}$ However, fear of adverse events, ${ }^{31}$ especially hematological toxicity ${ }^{32}$ in patients undergoing prolonged antibiotic courses, may preclude this strategy. In our whole patient population, that was exposed to oxazolidinones during the hospital stay, regardless of the focus of infection, thrombocytopenia and anemia were reported at discharge in relatively small numbers, $3 \%$ and $2.5 \%$. However, patients who also had this hematological diagnosis had a significantly higher mortality rate. Fear of this complication in patients discharged while receiving oral treatment with oxazolidinones may partly explain the long hospital LOS that we documented in SSSI. Compliance with oral treatment may also be lower than ideal and patients commonly overstate their medication adherence. ${ }^{33}$ This lack of compliance may increase therapeutic failure..$^{33}$

Moreover, patients with comorbidities may be at an increased risk of low compliance with antibiotic therapy in the ambulatory setting. This, along with the need for complex nursing (and even surgical) care, may preclude a plan for an early discharge. Finally, we believe that some of these patients died with an infection rather than died from an infection. In fact, this low rate of admission to an intensive care unit (only seven patients) seems to be related to a low perspective of recovery. A multidisciplinary approach, including plans for good palliative and nursing care at home may help improve patients' quality of life and to reduce hospital dependence and costs.

To facilitate the promotion of this ambulatory care, the use of antibiotics with a favorable pharmacokinetics (especially very long half-life) and safety profile, that maintain activity against the most common pathogens (including MRSA), facilitate patient adherence and are an important alternative to these patients, and thus facilitating early discharge and even cost control, could be an interesting complementary approach.

We acknowledge that this study has several limitations. First, we did not include a control group and could directly not compare hospital mortality or LOS; second, no microbiological documentation was studied; third, the number of patients included was low, probably due to underreporting; fourth, the study was retrospective, and this may have caused some unknown bias; finally, the diagnosis of 'oxazolidinone use' did not allow to discriminate patients who received this antibiotic early during their hospital stay from those who received it later, as rescue therapy. Furthermore, we do not know the total duration of the oxazolidinone treatment and that may be relevant, not only to evaluate efficacy but also to interpret our toxicity data. In fact, Soriano et $a^{\beta 2}$ clearly show a significant increase in both anemia and thrombocytopenia after 10 days of exposure. 


\section{CONCLUSION}

We believe that these findings provide a good perspective on the use of oxazolidinones in the therapeutic management of patients with SSSI. Unlike what has previously been suggested, this population, despite receiving oxazolidinones to treat SSSI, had prolonged hospital LOS and a high mortality rate. We think that this should be reassessed in further studies (either prospective or retrospective), focusing in patient details and assessing patient centered outcomes, i.e. not only hospital mortality but also hospital LOS and quality of life.

We believe that the improvement of the outcomes of this population relies mainly on a structured approach, including these drugs and others with a favorable pharmacokinetic and safety profile. Finally, a multidisciplinary plan, including not only clinical but also palliative care, is necessary to address this growing population in the ambulatory setting.

\section{PROTECTION OF HUMANS AND ANIMALS}

The authors declare that the procedures were followed according to the regulations established by the Clinical

\section{REFERENCES}

1. Moet GJ, Jones RN, Biedenbach DJ, Stilwell MG, Fritsche TR. Contemporary causes of skin and soft tissue infections in North America, Latin America, and Europe: Report from the SENTRY Antimicrobial Surveillance Program (1998-2004). Diagn Microbiol Infect Dis. 2007;57:7-13.

2. Edelsberg J, Taneja C, Zervos M, Haque N, Moore C, Reyes K, et al. Trends in US hospital admissions for skin and soft tissue infections. Emerg Infect Dis. 2009;15:1516-8.

3. Cardona AF, Wilson SE. Skin and soft-tissue infections: a critical review and the role of telavancin in their treatment. Clin Infect Dis. 2015;61:S69-78.

4. Zervos MJ, Freeman K, Vo L, Haque N, Pokharna H, Raut M, et al. Epidemiology and outcomes of complicated skin and soft tissue infections in hospitalized patients. J Clin Microbiol. 2012;50:238-45.

5. Lipsky BA, Weigelt JA, Gupta V, Killian A, Peng MM. Skin, soft tissue, bone, and joint infections in hospitalized patients: epidemiology and microbiological, clinical, and economic outcomes. Infect Control Hosp Epidemiol. 2007;28:1290-8.

6. Weigelt J, Itani K, Stevens D, Lau W, Dryden M, Knirsch C, et al. Linezolid versus vancomycin in treatment of complicated skin and soft tissue infections. Antimicrob Agents Chemother. 2005;49:2260-6.

7. Kamath RS, Sudhakar D, Gardner JG, Hemmige V, Safar H, Musher DM. Guidelines vs actual management of skin and soft tissue infections in the emergency department. Open Forum Infect Dis. 2018;5:1-6.

8. Vincent JL, Rello J, Marshall J, Silva E, Anzueto A, Martin CD, et al. International study of the prevalence and outcomes of infection in intensive care units. JAMA. 2009;302:2323-9.

9. Gonçalves-Pereira J, Pereira JM, Ribeiro O, Baptista JP, Froes F, Paiva JA, et al. Impact of infection on admission and of the process of care on mortality of patients admitted to the intensive care unit : the INFAUCI study. Clin Microbiol Infect. 2014;20:1308-15.

10. Dryden MS. Skin and soft tissue infection: microbiology and epidemiology. Int J Antimicrob Agents. 2009;34:S2-7.

11. Singer AJ, Talan DA. Management of Skin Abscesses in the Era of Methicillin-Resistant Staphylococcus aureus. N Engl J Med. 2014;370:1039-47.

12. Zilberberg MD, Shorr AF, Micek ST, Hoban AP, Pham V, Doherty JA, et al. Epidemiology and outcomes of hospitalizations with complicated skin and skin-structure infections: implications of healthcare-associated infection risk factors. Infect Control Hosp Epidemiol. 2009;30:1203-10.

13. Chapman AL, Dixon S, Andrews D, Lillie PJ, Bazaz R, Patchett JD. Clinical efficacy and cost-effectiveness of outpatient parenteral antibiotic therapy (OPAT): a UK perspective. J Antimicrob Chemother. 2009;64:1316-24.
Research and Ethics Committee and to the Helsinki Declaration of the World Medical Association.

\section{DATA CONFIDENTIALITY}

The authors declare having followed the protocols in use at their working center regarding patients' data publication.

\section{CONFLICTS OF INTEREST}

Helena Sofia Antão and João Paulo Guimarães are employees at Angelini Portugal. Filipe Froes and João Gonçalves Pereira have received advisory board and/or conference fees from Pfizer, Merck Sharp and Dohme and Angelini. Fernanda Paula Santos has no competing interests to declare.

\section{FUNDING SOURCES}

This study was funded by an educational unrestricted grant from Angelini.

The data used in this manuscript can be obtained from Administração Central do Sistema de Saúde (ACSS) upon request.

14. Stein GE, Schooley SL, Havlichek DH, Nix DE. Outpatient intravenous antibiotic therapy compared with oral linezolid in patients with skin and soft tissue infections: a pharmacoeconomic analysis. Infect Dis Clin Pract. 2008;16:235-9.

15. Li HK, Agweyu A, English M, Bejon P. An unsupported preference for intravenous antibiotics. PLOS Med. 2015;12:e1001825.

16. Wright BM, Eiland $\mathrm{EH}$. Retrospective analysis of clinical and cost outcomes associated with methicillin-resistant staphylococcus aureus complicated skin and skin structure infections treated with daptomycin, vancomycin, or linezolid. J Pathog. 2011;2011:347969.

17. Figtree M, Konecny P, Jennings Z, Goh C, Krilis SA, Miyakis S. Risk stratification and outcome of cellulitis admitted to hospital. J Infect. 2010;60:431-9.

18. Lipsky BA, Moran GJ, Napolitano LM, Vo L, Nicholson S, Kim M. A prospective, multicenter, observational study of complicated skin and soft tissue infections in hospitalized patients: Clinical characteristics, medical treatment, and outcomes. BMC Infect Dis. 2012;12:1.

19. Garau J, Ostermann H, Medina J, Avila M, McBride K, Blasi F. Current management of patients hospitalized with complicated skin and soft tissue infections across Europe (2010-2011): assessment of clinical practice patterns and real-life effectiveness of antibiotics from the REACH study. Clin Microbiol Infect. 2013;19:E377-85.

20. Stevens DL, Bisno AL, Chambers HF, Everett ED, Dellinger P, Goldstein EJ, et al. Practice guidelines for the diagnosis and management of skin and soft-tissue infections. Clin Infect Dis. 2005;41:1373-406.

21. Thibaut S, Caillon J, Lepelletier D, Lombrail P, Potel G, Ballereau F. Who are the carriers of MRSA in the community? A prospective study in the Pays de la Loire region of France. Clin Microbiol Infect. 2010;16:915-20.

22. Rajan S. Skin and soft-tissue infections: classifying and treating a spectrum. Cleve Clin J Med. 2012;79:57-66.

23. Bouchiat C, Curtis S, Spiliopoulou I, Bes M, Cocuzza C, Codita I, et al. MRSA infections among patients in the emergency department: a European multicentre study. J Antimicrob Chemother. 2017;72:372-5.

24. Nazareth R, Gonçalves-Pereira J, Tavares A, Miragaia M, de Lencastre $\mathrm{H}$, Silvestre J, et al. Infeção por staphylococcus aureus meticilina-resistente da comunidade em Portugal. Rev Port Pneumol. 2012;18:34-8

25. Tavares A, Miragaia M, Rolo J, Coelho C, De Lencastre H. High prevalence of hospital-associated methicillin-resistant Staphylococcus aureus in the community in Portugal: Evidence for the blurring of community-hospital boundaries. Eur J Clin Microbiol Infect Dis. 2013;32:1269-83.

26. Maijo M, Clements SJ, Ivory K, Nicoletti C, Carding SR. Nutrition, diet and immunosenescence. Mech Ageing Dev. 2014;136-137:116-28. 
27. Li Y, Xu W. Efficacy and safety of linezolid compared with other treatments for skin and soft tissue infections: a meta-analysis. Biosci Rep. 2018;13:38.

28. Yue J, Br D, Yang M, Chen X, Wu T, Gj L. Linezolid versus vancomycin for skin and soft tissue infections (Review ). Cochrane Database Syst Rev. 2016;1:CD008056.

29. Bally M, Dendukuri N, Sinclair A, Ahern SP, Poisson M, Brophy J. A network meta-analysis of antibiotics for treatment of hospitalised patients with suspected or proven meticillin-resistant Staphylococcus aureus infection. Int J Antimicrob Agents. 2012;40:479-95.

30. Dryden MS. Linezolid pharmacokinetics and pharmacodynamics in clinical treatment. J Antimicrob Chemother. 2011;66:S7-15.

31. Beekmann SE, Gilbert DN, Polgreen PM. Toxicity of extended courses of linezolid: results of an Infectious Diseases Society of America Emerging Infections Network survey. Diagn Microbiol Infect Dis. 2008;62:407-10.

32. Soriano A, Ortega M, García S, Peñarroja G, Bové A, Marcos M, et al. Comparative study of the effects of pyridoxine, rifampin, and renal function on hematological adverse events induced by linezolid. Antimicrob Agents Chemother. 2007;51:2559-63.

33. Eells SJ, Nguyen M, Jung J, Macias-gil R, May L, Miller G. Relationship between adherence to oral antibiotics and postdischarge clinical outcomes among patients hospitalized with staphylococcus aureus skin infections. Antimicrob Agents Chemother. 2016;60:2941-8.

34. Antão HS, Guimarães JP, Froes F, Almeida J, Marques S. Dalbavancin: a new pathway for the treatment of acute bacterial skin and skin structure infections in Portugal. Health Econ Outcome Res. 2017;3:1000138. 